University of Massachusetts Amherst ScholarWorks@UMass Amherst

Masters Theses 1911 - February 2014

1937

\title{
Effect of apples, tomatoes and dates on urinary acidity and blood alkali reserve
}

Kevin Griffin Shea

University of Massachusetts Amherst

Follow this and additional works at: https://scholarworks.umass.edu/theses

Shea, Kevin Griffin, "Effect of apples, tomatoes and dates on urinary acidity and blood alkali reserve" (1937). Masters Theses 1911 February 2014. 1956.

Retrieved from https://scholarworks.umass.edu/theses/1956

This thesis is brought to you for free and open access by ScholarWorks@UMass Amherst. It has been accepted for inclusion in Masters Theses 1911 -

February 2014 by an authorized administrator of ScholarWorks@UMass Amherst. For more information, please contact

scholarworks@library.umass.edu. 


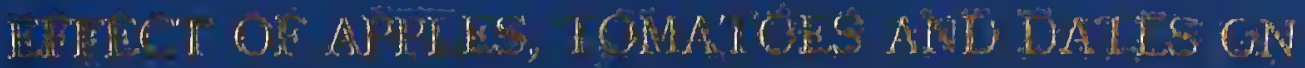

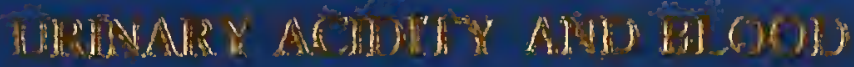

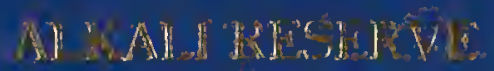

Wha $\operatorname{rog} 7$ 

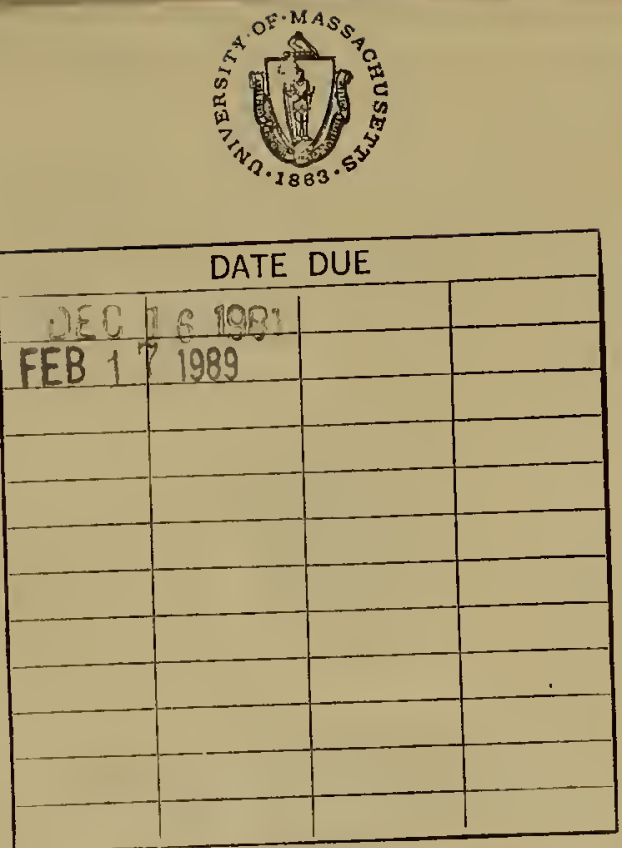

UNIVERSITY OF MASSACHUSETTS LIBRARY

PIIYS SCI

LD

3234

.1268

1337

5537

PHYSICAL SCIENCE THES IS 
FFFECF OF APPLES, TOLATOES AMD DAFES ON URINARY ACIDIPY AND BLOOD

ALKALI RESERVE

KEVIN G. SHEA

Thesis Subnitted for the Degree

of Laster of Selence

UASBACHUSWPTS STRTE COLLEOE

AXHERST

MAY 25, 1937 
TABLE OF CONTENTS

\section{INTRODUCTION}

OBJECT

REVIE OF LITERATURE

UETHODS

\section{Diet}

Urine Anelys1:

Proximate Anilyis of the Frulto

TABLE OF THE COEPOSITION OF THE FRUTS

RESILTS

Tables I-IX

DISCUSSIOR OF RESULTS

SIMMARY

GENERAL CONCLUSION

BIBLIOGRAPIY 


\section{INPROJUCTION}

It 1 a a well known physlological phencmenon that certaln acld fruitg, such as oranges or tomatoes, after passing through the body have an alkaline effect on the urine and increase the alkall reserve of the blood plasma. This effect 18 explained as being due to an excess of base furming elements which remaln after the aclds are oxidized in the body.

Certain other fmults, such s.s cranberries, have been founa to have an opposite effect. Their ingestion results in a lowering of the urinary $\mathrm{pH}$ and also a lowering of the alkall reserve. This is due to the effect of aromatic actas such as benzolc acld and $1 \mathrm{t} s$ precusor quinic acld. These aclds are confugated with glyclne, which is thought to bo synthesized in the 11 ver, and so are excreted to lower the pll of the urine. other organic aclas such as tartarlc are oxidized but not completely so, and, therefore, a eractional portion of the original fruit acld is excreted in the urine.

\section{ODJECT}

As nost frult aclas are oxidized to carbon dioxide and water in the body, or otherrige ut1lized, the ash constituents, rather than the organlc aclds, are the more important factor regulating the aclid-base balance of the body. This research was undertaken to determine the effect of apjles, dates, and tomatoes on urinery aclatty and blood alkall reserve. The results of this investigation should have a definite therapeutic 
value in that the malntenance of an adrequate alkall reserve 18 of fundamental importance. Information as to the effects of frults should be of value in the cholce of diet in the case of acloosis.

\section{REVIEY OF ISITERATURE}

Saywoll(7) in his work on grape products found a declded increase in the $\mathrm{pH}$ value of urine, a decrease in ammonia and a corresponding decrease in total acialty. He reported an increage in the alkal1 reserve and a glight but apnarent increase in organlc aclalty, which he explained a belng due to some incompletely oxidized tartaric acid.

Seywell(B) also recorted in another psper that flgs had the same genersl effect as prape products. However, he found that 97.5 percent of the organic acids were oxidized before being eliminated from the system.

Blathervick and Long (2) concluded that drinking large amounts of orange juice resulted in the production of an alkaIne urine. Saywell(9) in hls work on orange and tomato julces observed on the 1ngestion of these frult juices, the same effects as were produced when iprepo products were used, Including the increase in organic acldity. He found that there was a correlation between the alkalinity of the ash and the reaction of the urine. He also found that 82.5 percent of the total alkalinity of the tomato julce ash is derlved from the water soluble ash, which is excreted in the urine, while the soluble alkalinity of the oran?e julce ash is only about 65 
percent of the total alkallnity of the ash. Saywell (10) also reported that fresh Bartlet pears, canned peaches, canned apricots and dried sulfured apricots produced results in urine similar to those produced by grape products. He found that 94.7 percent was the everage percntage oxidation of the organic aclids of these foods. Blatherwick and Long (2) have shown that large amounts of orange julce produced an increase in $\mathrm{pH}$ with a decrease in the ammonia content of the urine.

Cleveland and Fellers (3) reported that the percentage of ash in dates, aporoximately 2 percent, is two or three times that of most foods which yleld an alkaline ash. The alkalinity of the ash is high because of the large proportion of potash. Ash from 100 grams of a moisture free portion 18 equivalent to 16.7 cublc-centimeters of ro.mal alkal1. This can be compared with tomatoes, which have a value of 5.6 cubic centimeters and apples which approximate 3.7 cublo centimeters according to Sherman (1I).

Blatherwick (1) found that the addition of ralsins to an otherwise ac1d diet resulted in decreased acldity of the urine. He also reported, in the same paper, that tomatoes produced signiflcant changes in the urine, the pH being increased and the ammonia excretion belng decreased. Apparently, fresh whole tomatoes were used.

METHODS

Elght male human subjects in good health and from 22 to 27 years of age were used in this investigation. They are de- 
slgnated as C, D, J, K, ( $, L, S$, and F. Four subjects were placed on a aAly basal diet which vas aporoximately nautral. It consisted of:

Grahan Crackers

$300 \mathrm{~B}$.

m1k (3 pints)

$730 \mathrm{~g}$.

Let tuce

$120 \mathrm{~g}$.

Heavy Cream (1/2 pint)

$225 \mathrm{~g}$.

$\operatorname{Eg} 8$ (2)

1408.

Flve subjects were placed on a dally basal diet which was acld forming and consisted of:

\section{Breakfast}

Oatmea 1

Egrs (I)

Cream

Sugar

Bread

Butter

II $1 \mathrm{k}$
Lunch

greme

30

80

30

10

40

14
Salmon

Bread

Let tuce

Cook1es (plain)

IIIk

250

Supper

Peas (Iona) $8 \frac{\text { ram }}{191}$ Beef steak (cube)

150

Bread

Butter

Let tuce

Cook1es

The subjects were placed on thelr respective basal alcts for a sufflclent length of tire to allow their tissues to rasch eodilibrium. This anounted to three to four days except in the case of the dates where the prellminary basal period was two daye Then to these basal diets there was added a derinite amount of the material to be tested, the amounts beinf, in general, much greater than would bo ingested under norral conditions. I'he efrect of this addition should be reflected in the urinary acldity and in the alkall reserve. The last tro days of the det perlod consisted rrain of the basal diet. Ho urine was collected during the first two or three deys but 24 hour collec- 
tlons pere made and analyzed at the end of each collection period on all subsequent days. The collection period was from 8 A. H. to 8 P.H.

As previously mentioned there were two diets, one acid and one apcroximately neutral. The neutral basal diet was chosen because the effects of the material to be added, on the urinary acidity could not be definitely foreseen. The acld forming basal alet was ut111zed because $1 t$ was believed that the 1ngested materlal would increase the alkalinity of the urlne, and beckuse such a result would seemingly be more evident on an acld alet. This was thoughi to be especially true as regards the dates, the analyses of which showed an exceptionally high alkalinity of the ash.

Four different materials were tested in four different experiments. The Plrst was run on McIntosh apjles, the second on Balawin apples, the third on tomatoes and the fourth on dates. Large quant1ties(800 and 1000 grams) of the 11 rat three vaterials and a saller quantity ( 400 grans) of the dates were fed in these trials. The ratio of edible portion to pit is varlable in the different varleties of detes, but at a definite nolsture content is relatively constant for a given variety. The dates used were of the Hallowl variety and averaged 88 percent of plesh and 12 percent of pit.

The methods comonly used in urine analysis were eminged. The pH was determined by uning a quinhydrone potentiometer. T1tratable ac1diiy was determined by Folins' method which 18 
a simple titration of urine aggeinst tenth normal sodium Hydroxide using phenolphthalein as an inalcator. The organlc aclids were titrated using the Van Slyke and Palmer Technlc (2). Urea nitrogen was determined by the urease method. (6) Anmonia nitrogen by the Folin and Bell method (4), and creatinine by Folin's method (5). The figures in the tables whloh represent the amounts of the determined constituents of urine are expressed in terms of grams per 24 hours in all caves except that of titratable aclalty and organlc aclatty which are reported in cublc centimeters of tenth nomal acla in 24 hours. The alkall reserve is expressed as cublc centimeters of carbon dioxde in 100 cuble centimeters of blood plasma.

F1tz and Van Slyke (13) have shown that in normal men "The excretion of acld in excess of flxed bases as mensured by detemining the amonia and titratable acld bears a quantitative relationship to the alkall reserve of the body a moasured by the $\mathrm{CO}_{2}$ binding power of the blood plasma". They developed a formula by which, using data obtalned from urine analyses, it 13 possible to calculate the alkall reserve of the blood plasma. In their stuales vith nomal individurls, the value of the rlkall reserve as deteranined in the urine usually had an average error of 3.2 volume percent.

The dally collectlons of urine were kept in a refrigerator to prevent bacterial decomosition. A snall anount of toluene was added to help the pregervative action. 


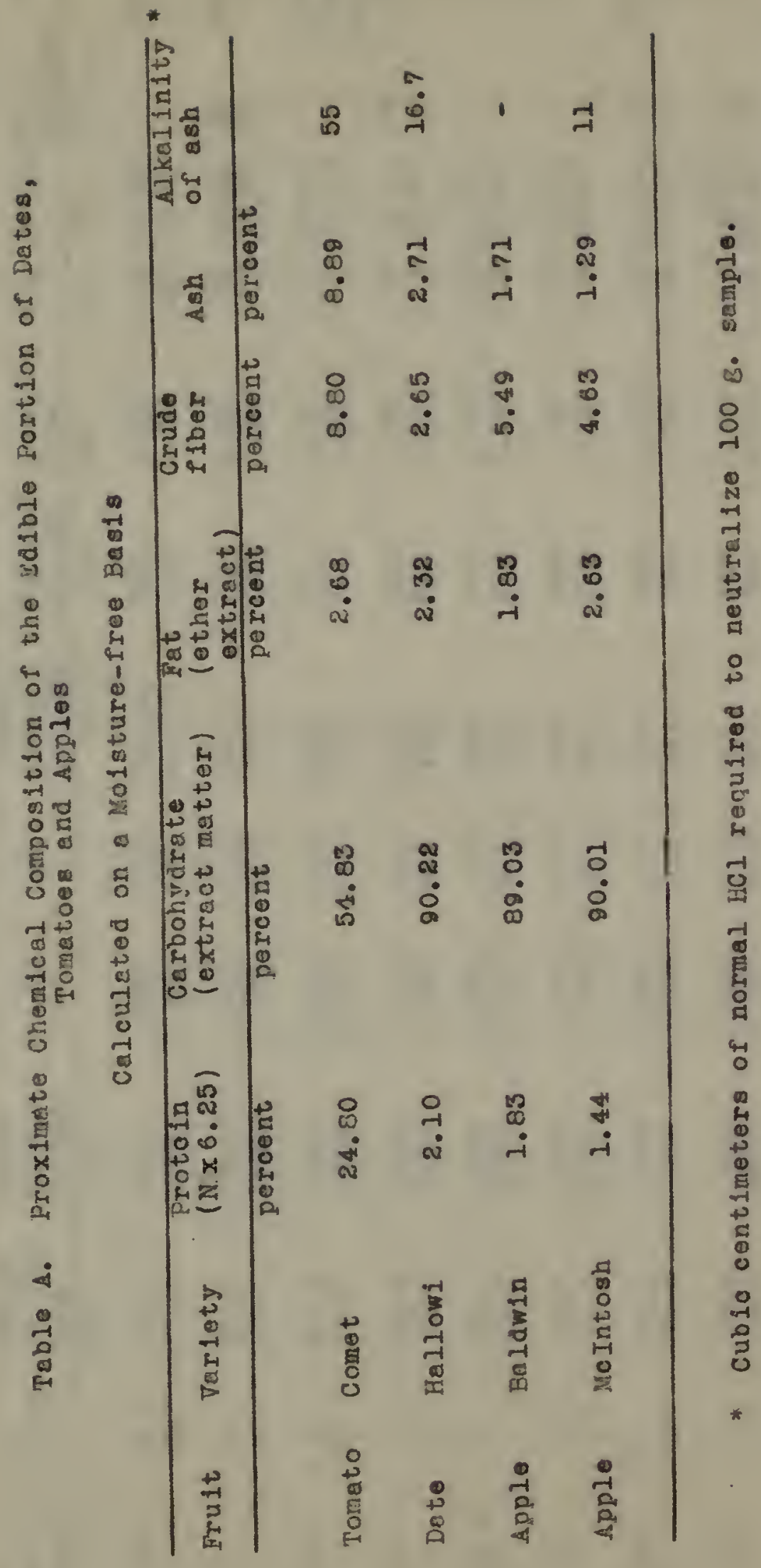




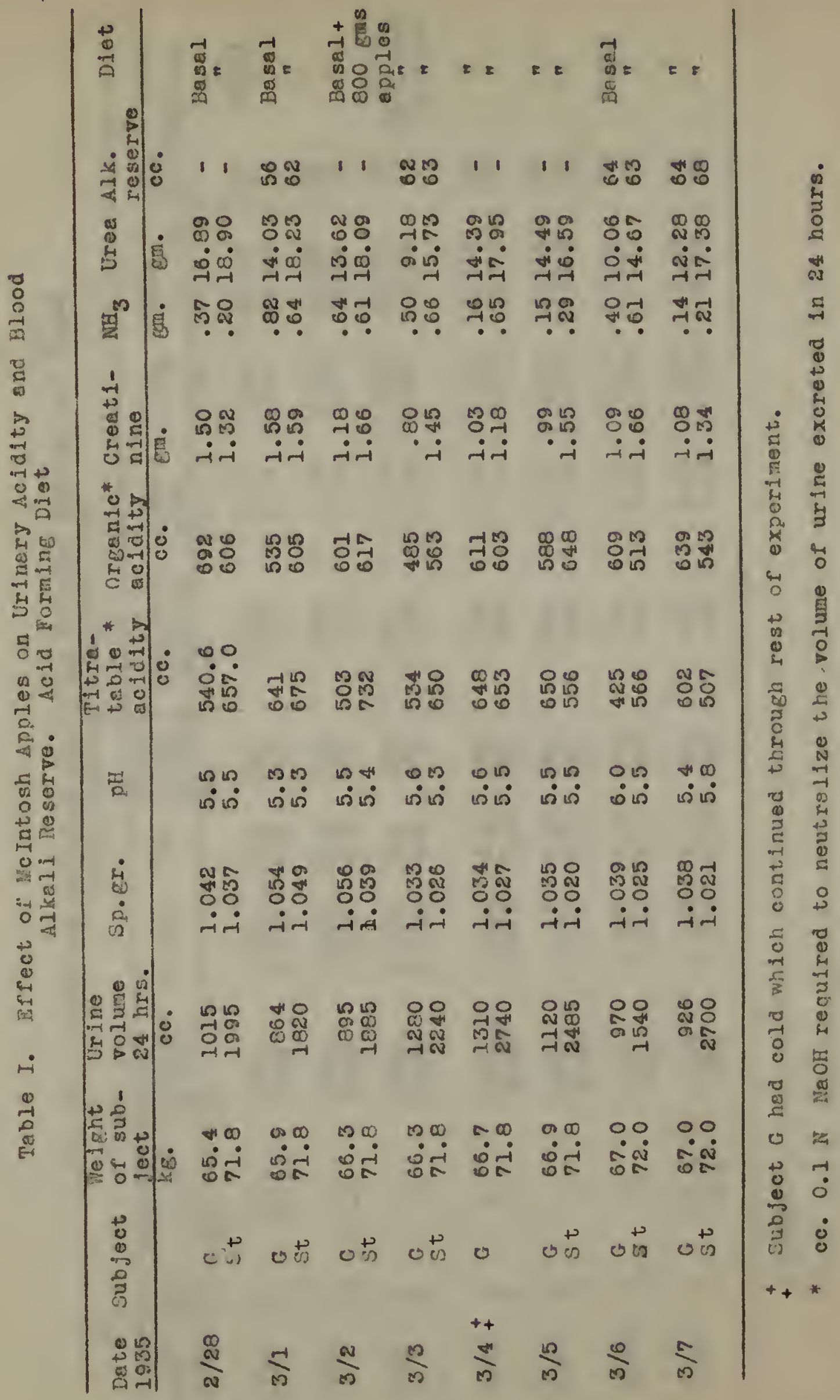




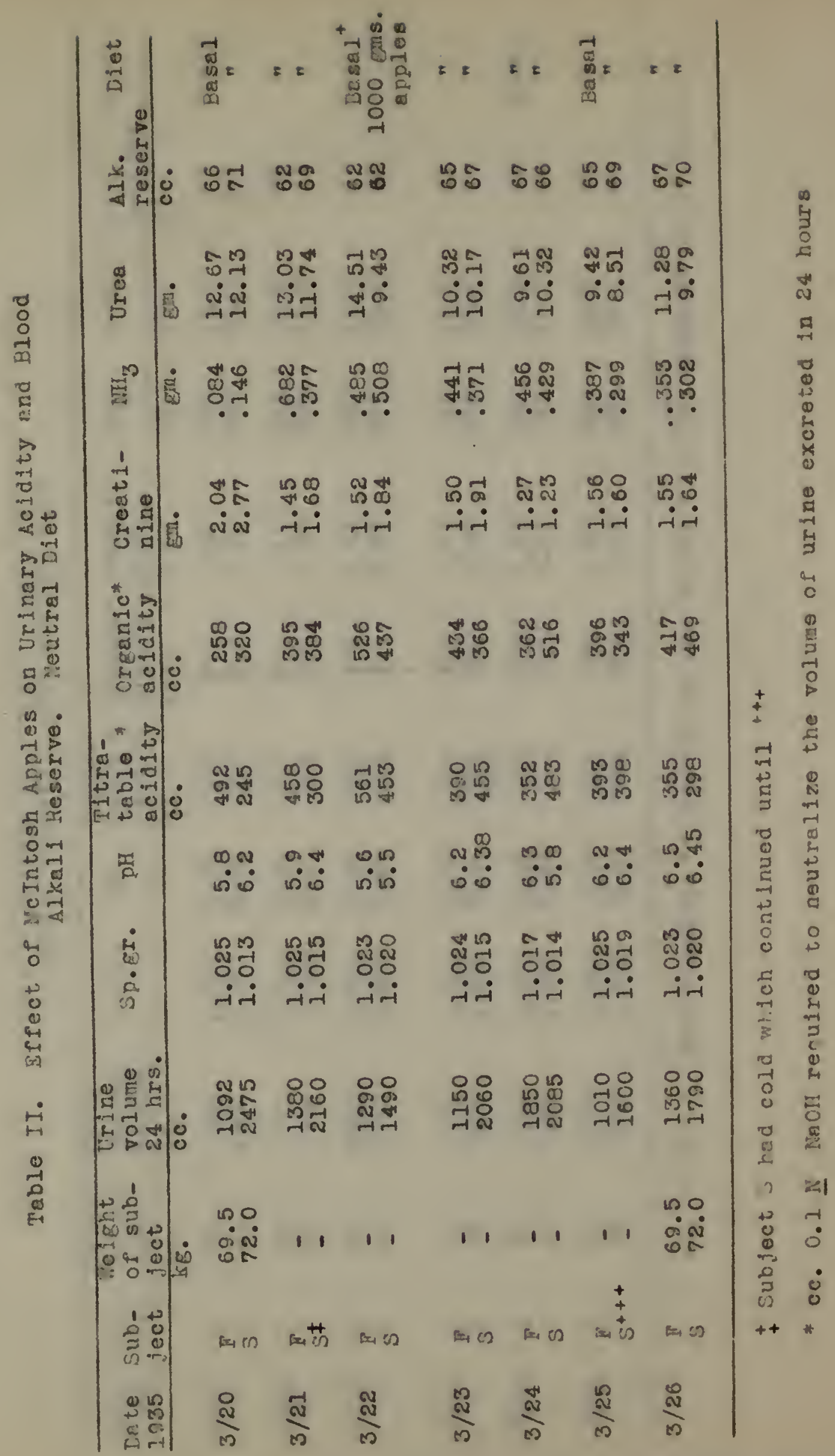




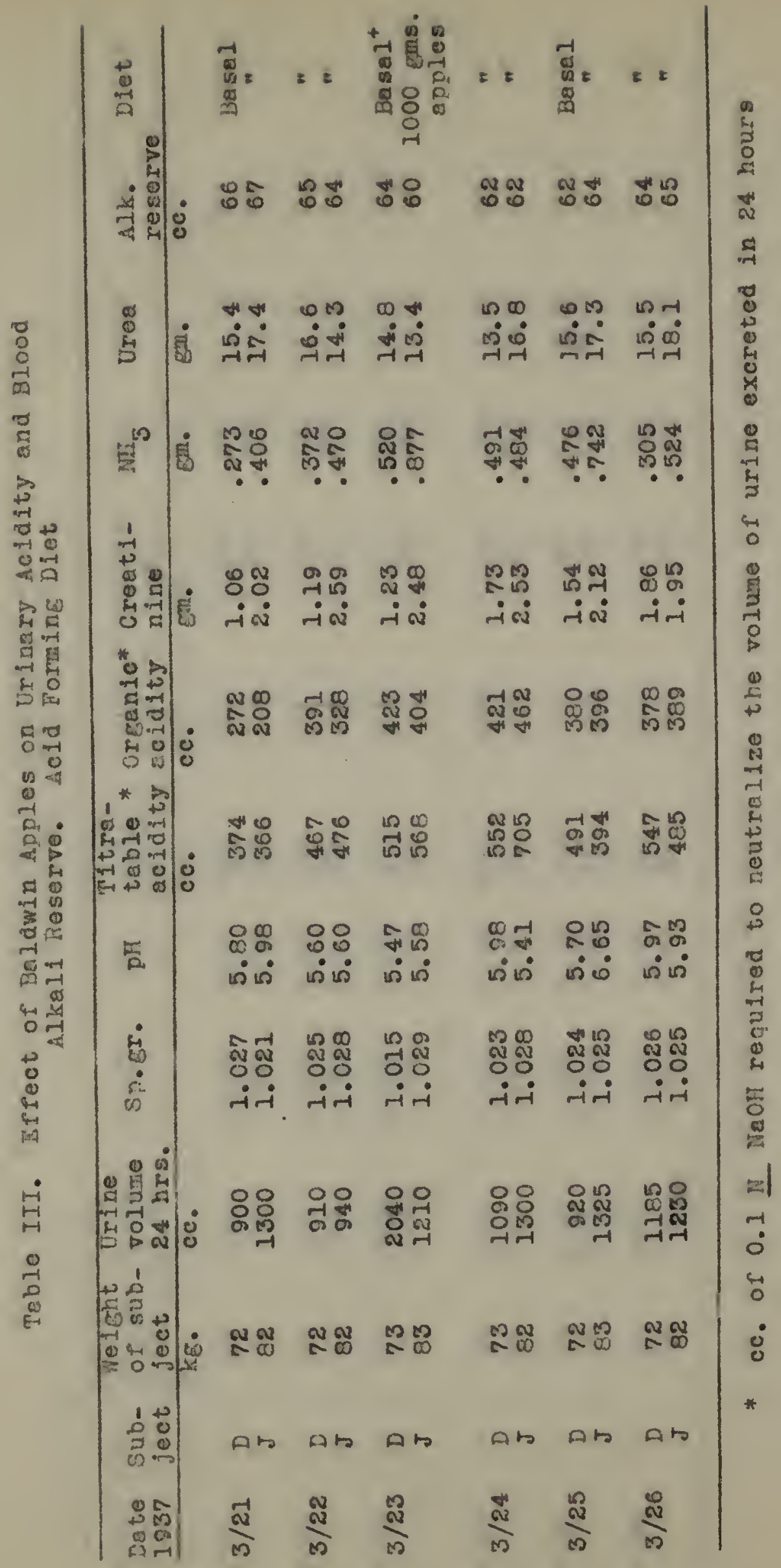




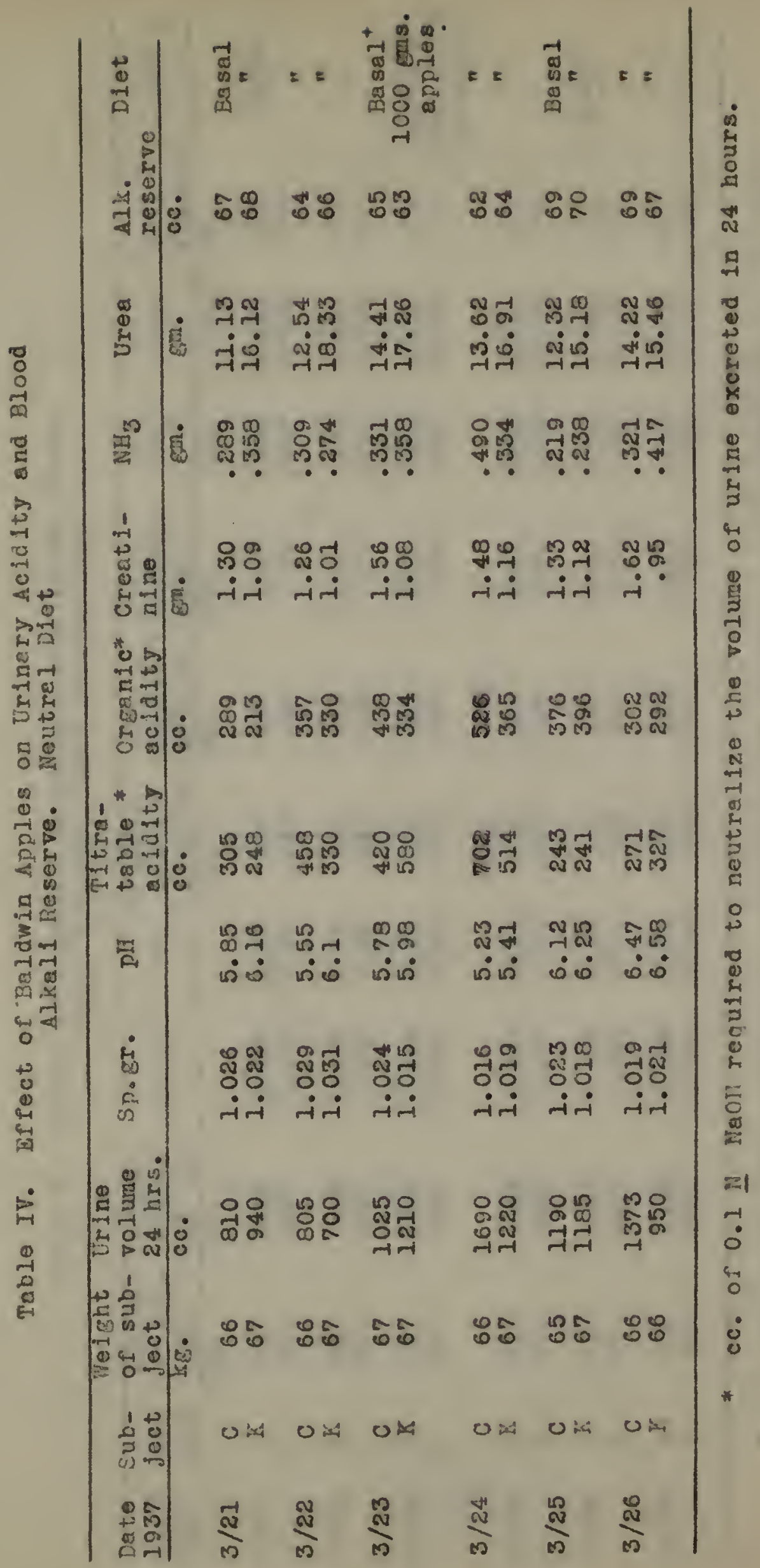




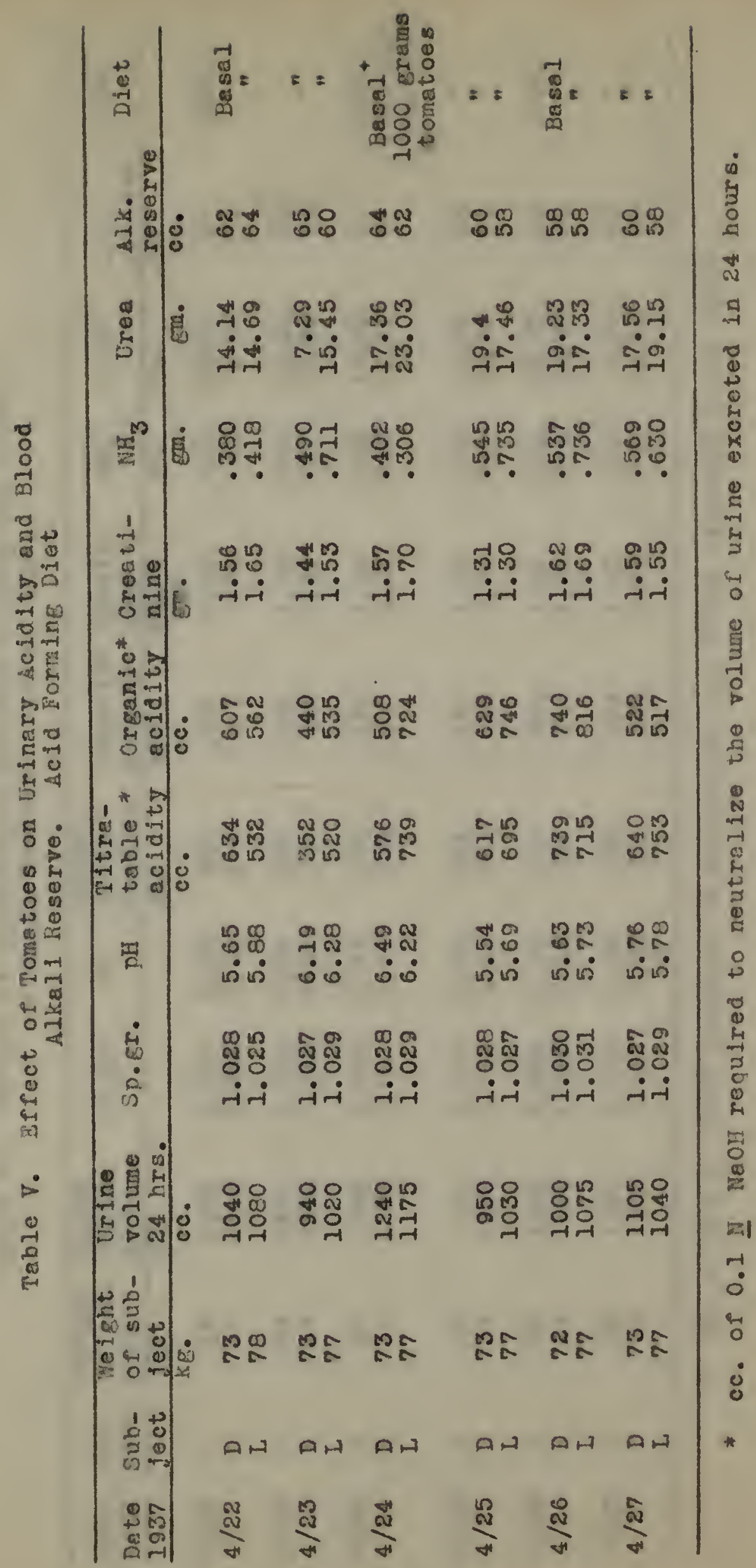




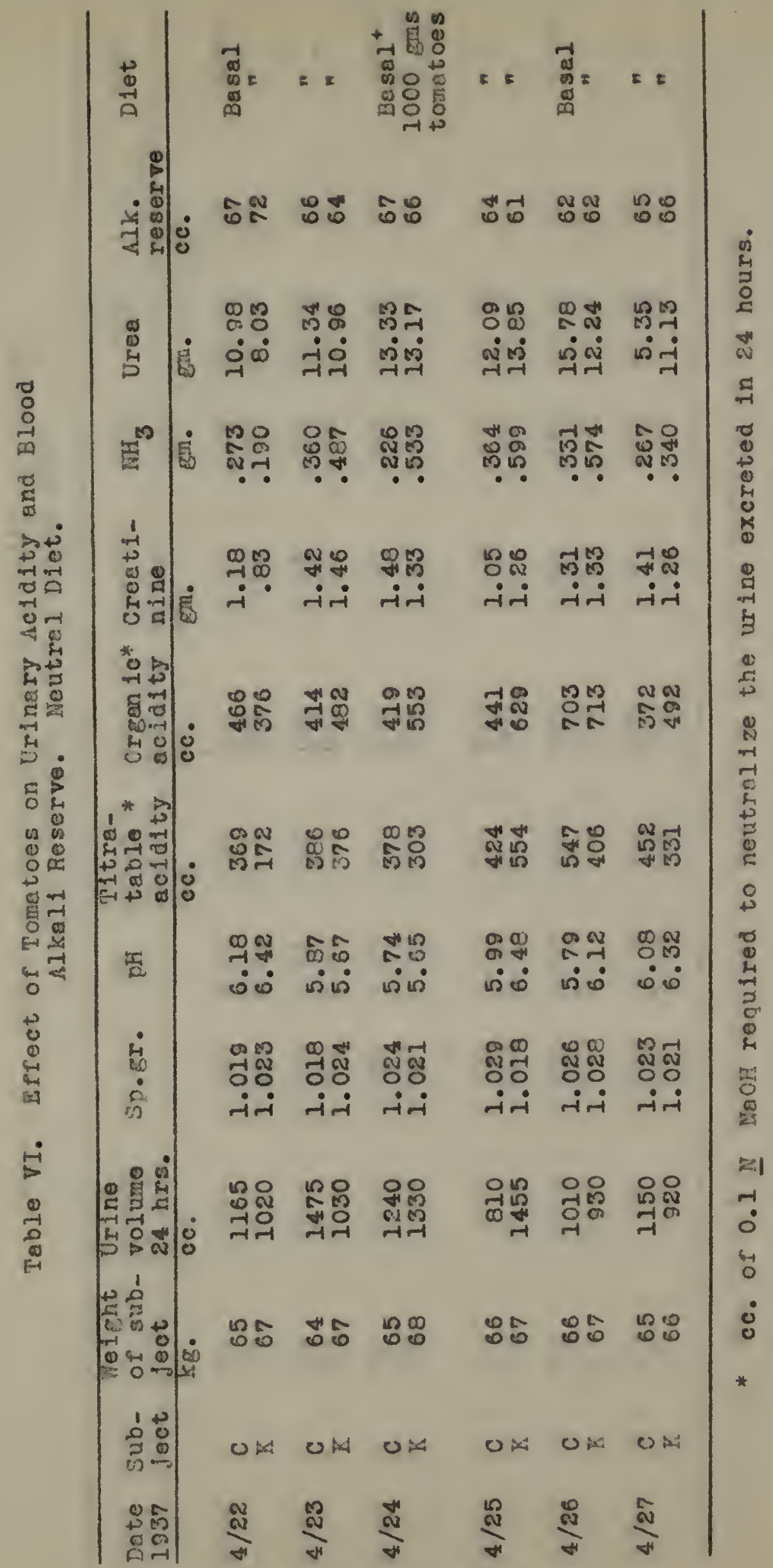




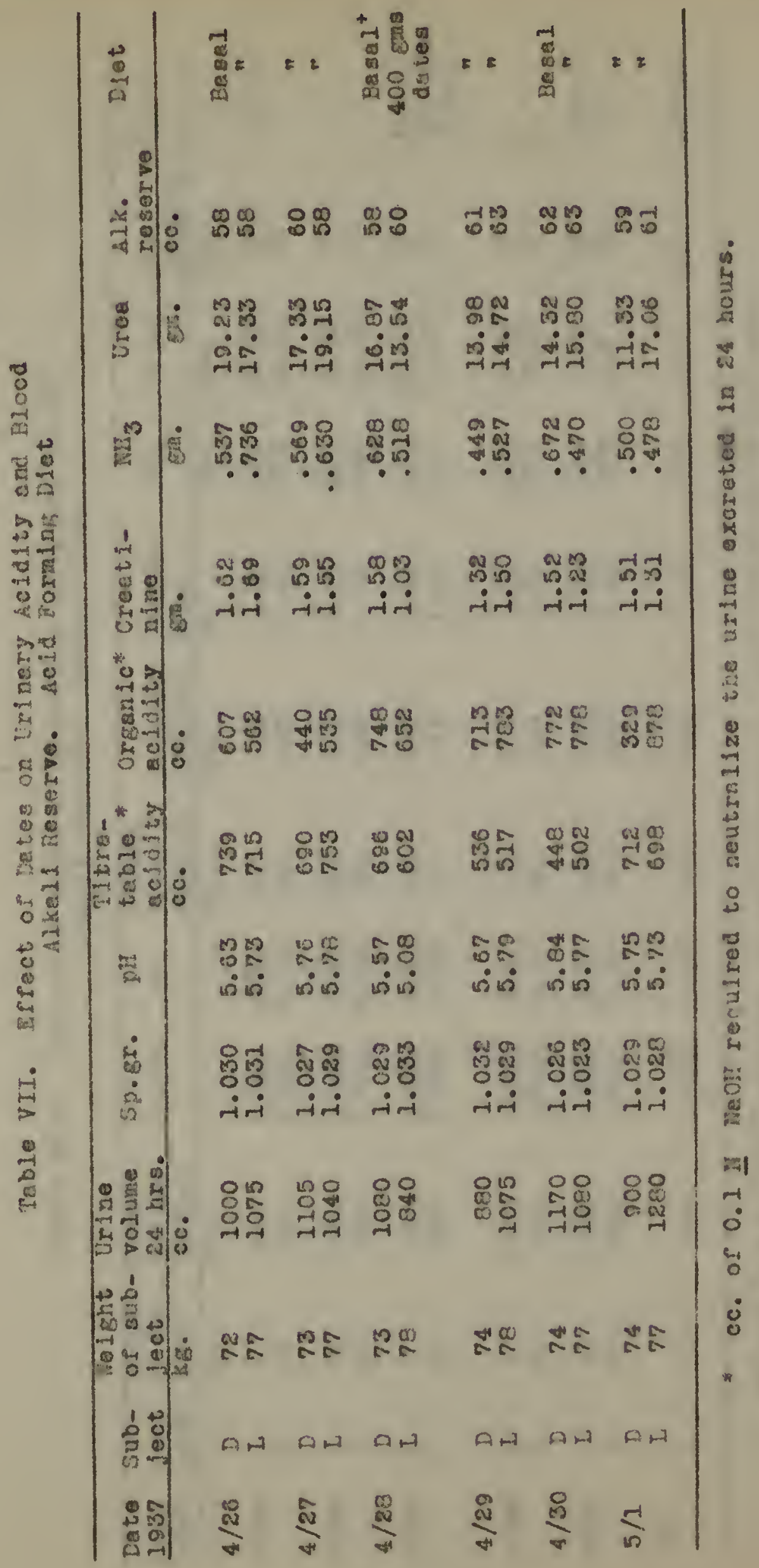




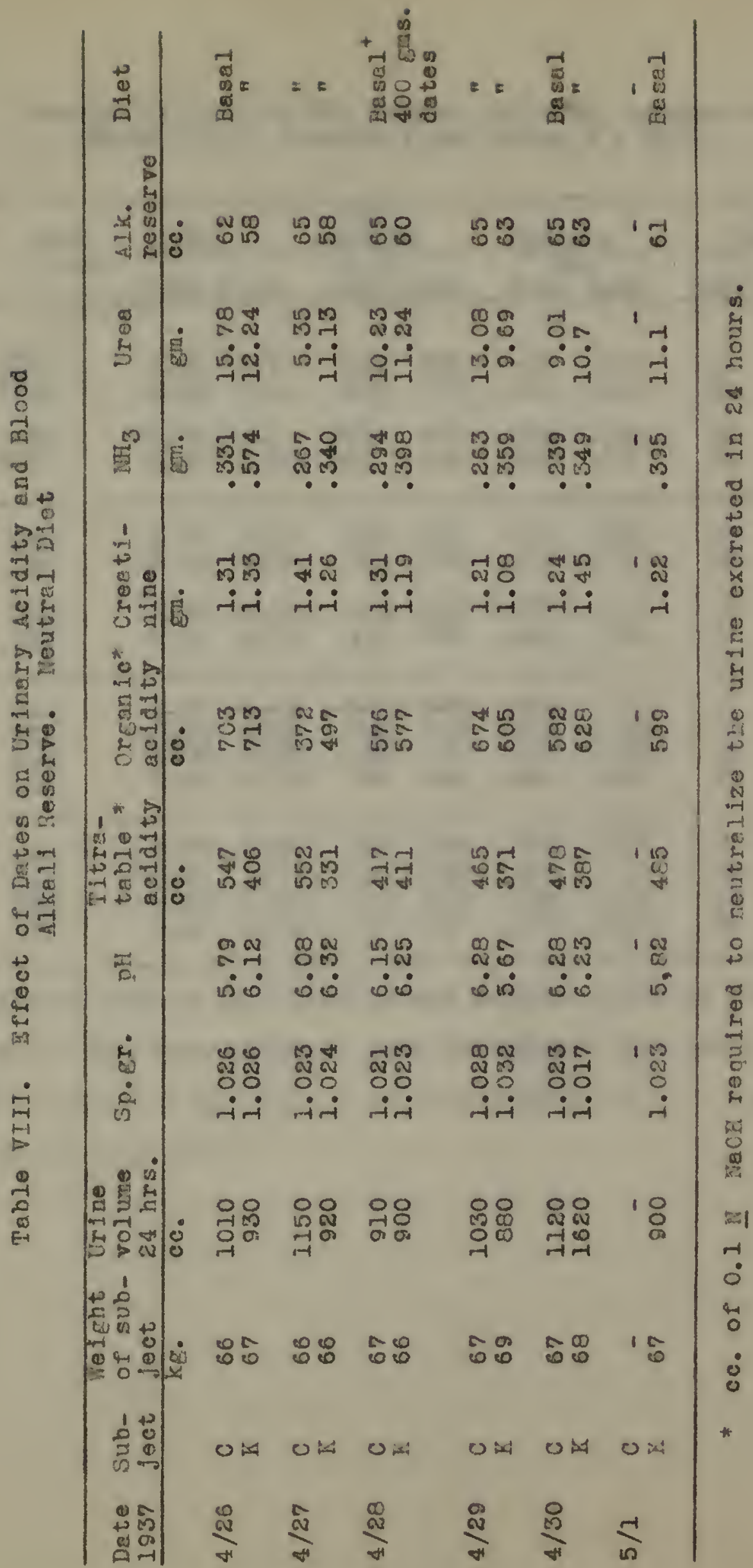


Table IX. Summary of Data on pH, Organic Aclalty, Amonia and Blood Alliald heserve from rables I - VIII

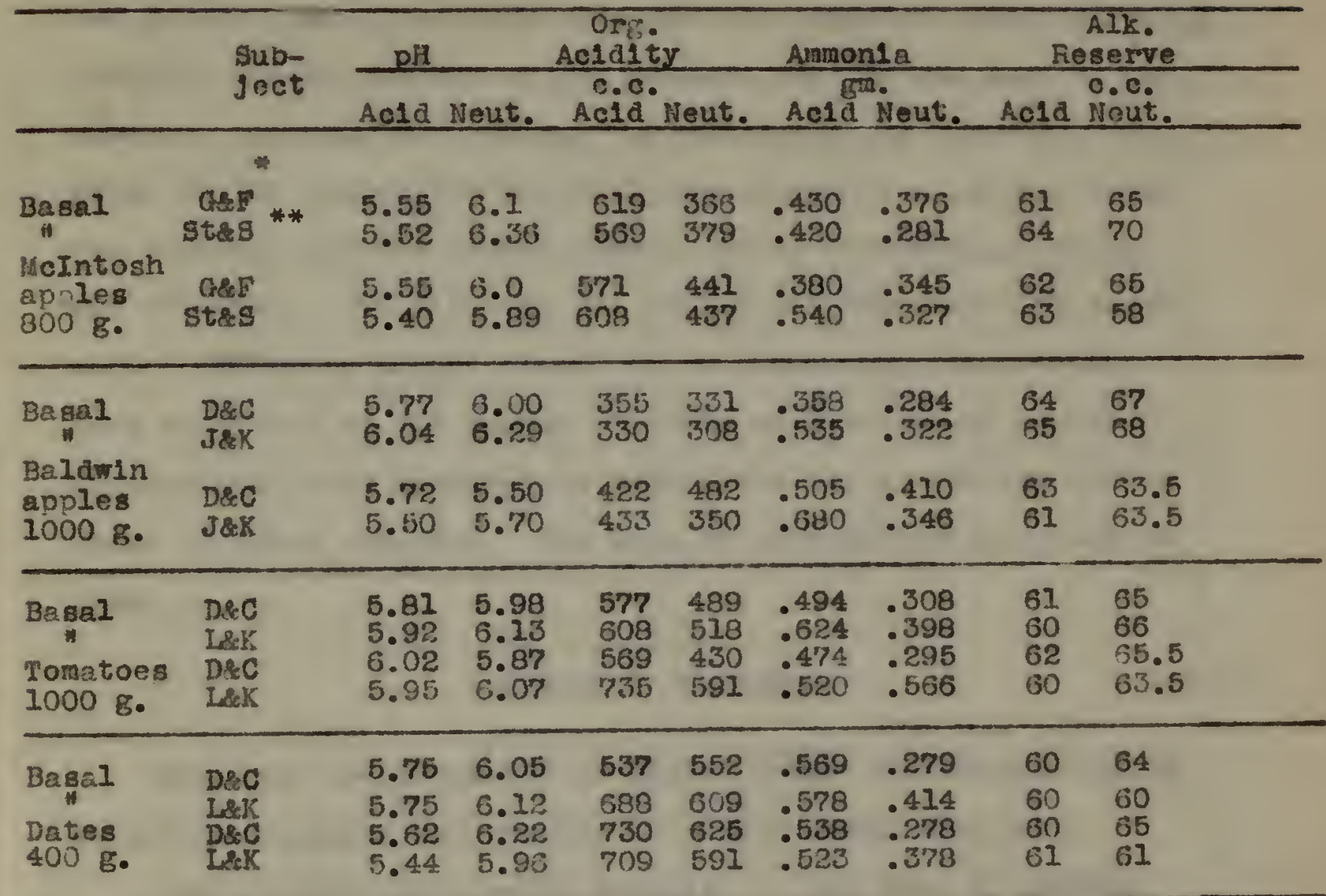

* Subject $G$ was on acid forming and subject $F$ mas on the neutral alet. The same order is used throughout this table. **"St" refers to "S" when on an ac1d-forming diet. They refer to the same subject. 
The proxlinate compostion of the food materlalo used was determined in poneral by the official methods of analysis of the Association of officlal Apricultural Chemats (1935 Eation). However, the nltalingty of the coluble nsh, in the case of the tomatoes and heIntosh apples, wns determined as follows. Two grams of the deslecated material were ashed at a low red. heat. The reglduel ash was washed several times with bolling water and filtered. The filtrate wos cocled and titrated pith tenth nomel HCL usinf methyl oranfe as an indlcator. The results were expressed as the number of cublo centimeters of nomal hydrochloric acla required to neutralize the glkalinity of 100 grems of ashed materisl. The data on composition are fiven in Table A.

\section{DIECUSSTON OF MESLLAS}

The date are presented in Tables I-IX. The Sumary Table IX brings together the results in easly comperable form.

The results are largely negetive ir the case of Baldwin and NeIntosh apples, tomatoes end dates regardess of whether an acld produclng or a neutral basal diet was used.

The alkall reserve was not slgniflcantly affected by any of these Prults eaten 1 quantities of from 40 to 1000 grams. Whe pll, orgenic aclds and titratable acld values for the 24-hour samples of urine collected from the sublects showed some variations but no significant changes as a result of the pult alets.

Apparently the organlc aclas of apples and tomatoes sre readily oxldized or otherwise transformed in the body so that 
very $11 t$ te is excreted in the uxine. The results of Saywe1l and Lane (9) are discusged under tine I1terature rov1ev in this paper. They found an oxidation of 90.7 percent in the orgenic acids of the tomato. An increase in urinary pil wa also noted by thesa. No provlous research has been raported on apples or dates.

In the acid produclug dets, Baldwin apples, licIntogh apoles, tonatoes and dates showed respectively, 89.3, 93.2, 81.0 and 75.9 percent util1zation of the ingested frult organlc acids. In the noutril diet the percentages of the orgentc actes oxldized for Baldwin epples, McIntosh apples and tomatoes are $85.0,83.3$ and 90.8 . The data on dates was of doubtful value and are not 1 ncludied. Seymell $(7,8$, 10) states that the frult organic relds anpear to be "oxidized". Whetlier actual oxidation ocours is uncertain.

That 1B, even when assive amounts of fruits axe eaten, appraxinately 90 percent of the organic acids pregent in them are oxidized or otherrise changed in the body and do not appear in the urine or blood as free aclds. Whother actual oxidation oocurs is uncertain, hence the term "oxidation" is probably not warranted.

There is algo the possiblilty that some of the orpanic aclds apnearing in the urine may be synthesized in the body and exoreted. If this is true, the assumption rade by Sayme11, and followed in thls paper, that all the urinary organic aolds found in the urine are derived from the frult eaten, may not be entirely correct. 
The blood elkall reserve data are particularly constant throughout these experinents. Only in the apple diet ras there even a gall reduction of this value. The greatest single reduction was in the case of weIntosh apples fed in the neutral diet. Here the arop was from 70 to 58 cublc centimeters. Attention is arawn to the remarkablo similar1ty of the urine constants among the alght subjects used in these experiments. 


\section{SUIDAARX}

1. The proxinate cherical comocition of apples, tomatoos and artes is given.

2. In nomel young humen subjects Baldwin and McIntosh npples behave simliarly when infested in 800 and 1000 gram amounts. Both varietles lower sIlghtly the pH of the urine, but do not signiflcantly afrect the blood alkall reserve in human aubjects. 3. Approximately 90 percent of the orranic acids of apolec are comoletely oxillzed or othorise transfomed in elther seld forming or neutral diets.

4. Acld-fuming and neutral diet. geve gimilar regults in these experiments insolar as acld and ammonia excretion in the urine and blood plkall reserve are concerned.

5. Tomatoes and dates hive perticuliy no effect on the comnosition of the urine nor on the blood alkall reserve. Meutral and ecichormine dets geve closely stmilar results. 6. Aonroximetely 34 nercent of the orpanic aclds of the tometo were completely oxidized or othemise transformed when towatoes were included in an acld foming diet, whlle this value was 91 percent in the neutral niet.

7. Dates were aten in salier quantities than tomatoes and apoles, and no signlflcant results on the urine or blood alkali reserve were noted. In splte of the high alkalinity of the ash of dates, the pH of the urine was not increased nor the orgenic ac1ds decreased in minount. 


\section{GENERAL CONCLUSION}

Massive amounts of apples, tomatocs and rietes way be eaten without signiflent effect on urinery aclalty or blood alkal1 reserve. 


\section{BIBLIOGRAPIX}

I. Blatherwlck, M. R., Arch. Int. Mel., 1914, 14, 409.

2. Blatherwlek, W. R., and Long, K. L., Jour. B10I. Chem., $1922,63,103$.

3. Cleveland, M, M., and Fellers, C. R., 1932. Ind. Eng. Chen. Anal. $\mathrm{Ed}$. 4, 267.

4. Fol!n, 0., and Be11, R. D., Jour. B101. Chem. 2017, 29, 329.

5. Folin, 0., Amer. Jour. Physiol. 1905, 13, 48.

6. Folin, 0., end Younghurg, G. E., Jour. B101. Chem, 1019, 36, i11.

7. Saymell, L. (7., Jour. Nutrition, 1932, B, 103.

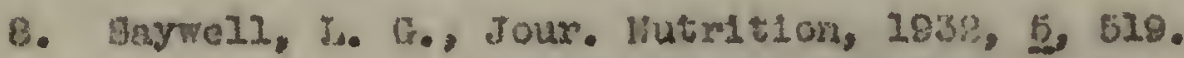

9. Seywe 1I, L. C. anả Lane, E. W., Joux. Nutrtion, 1933, ㅌ․, 233.

10. Saywe11, L. G., Jour. Nutr1tion, 1933, 6, 397.

11. Sheman, H. C., Food Proviucto, D. 354, IRach111an Co., 1910.

12. Van Slyke, D. D., and Palmer, H. "., Jour. Mol. Chere, $1019,30,111$.

13. Var slyke, D. D., Tour. B101. Chem., 1917, $20,330$. 
Approved by:

CareRtecen

opperid fimack

Gracuato fonmittee

Date June 7,1937 
